\title{
Review on Benefits of Owning Companion Dogs among Older Adults
}

\section{Kung Choon Keat}

Health Psychology Programme, Faculty of Health Sciences, Universiti Kebangsaan Malaysia

Email: kungchoonkeat@gmail.com

*Ponnusamy Subramaniam, PhD

Health Psychology Programme, Faculty of Health Sciences, University Kebangsaan Malaysia

*Correspondence Author Email: ponnusaami@ukm.edu.my

Shazli Ezzat Ghazali, PhD

Health Psychology Programme, Faculty of Health Sciences, Universiti Kebangsaan Malaysia

Email: shazli_ezzat@ukm.edu.my

Noh Amit, PhD

Health Psychology Programme, Faculty of Health Sciences, Universiti Kebangsaan Malaysia Email: nohamit@ukm.edu.my

\section{Doi:10.5901/mjss.2016.v7n4p}

\section{Abstract}

\begin{abstract}
Background: a world that is facing major global demographic trend of population ageing as well as increasing number of pet ownership, the benefits of companion animals on older adults is a noteworthy area of study. Objectives: To conduct a literature review on the existing studies focusing on the benefits of companion dogs on older adults. Method: Narrative review on original published articles in both Western and Asian countries pertaining to the benefits of companion dogs for older adults were conducted. Discussion: The benefits of companion dogs on older adults were analyzed in the domains of physical well-being, psychological well-being and social interaction. Most of the research papers included, suggest positive correlation between dog ownership and owner's well-being but a few papers also found no correlation between dog ownership and owner's general well-being. Conclusion: Even though companion dogs might not be for everyone and their benefits on their owners could not be determined conclusively, it is undeniable that companion dogs do play an important role in contributing to the well-being of their owners whether it is in the form of increasing social contact, motivation for exercise and reducing stress.
\end{abstract}

Keywords: Companion dogs, older adults, benefits, dog ownership

\section{Background}

The benefits of owning companion animals such as dogs and cats among older persons have always been a research interest for many researchers and practitioners within the field of mental health. This area of interest is becoming increasingly significant possibly as a result of the many parts of the world that are now facing major global demographic trend of population ageing (United Nation, 2013). This phenomenon has subsequently led to the increased attention in health related issues involving older person. Statistics collected by Pet Food Manufacturers Association, PFMA shows that there are a total of 8.5 million pet dogs and 8.5 million pet cats in the UK alone as of year 2013, which accounts for $25 \%$ and $19 \%$ of British households respectively. This finding demonstrates the fact that companion animals such as dogs and cats are an integral part of many households, thus making their role in their respective household an important one.

Companion dogs were often found to bring about benefits such as nonevaluative support that could act as buffer for stress (Allen, Blascovich, Tomaka and Kelsey, 1991), reduction in fear of being a victim of crime (Serpell, 1990) and staving off social needs deficits due to rejections (McConnell, Brown, Shoda, Stayton and Martin, 2011) to their owners. The importance of companion animals such as dogs and cats are valued in many parts of the world and researches have been conducted in various countries. This study therefore aims to identify the potential benefit that companion dogs could 
have on older adults from both western countries and Asian countries.

\section{Methods}

The narrative review method was used because it's given a broader overview of relevant information (Garg, Hackam \& Tonelli, 2008) and more useful tool for synthesis primary studies (Cipriani \& Geddes, 2003) compared with other type of review. Furthermore, narrative overview is useful educational article because it gathers a wide range of readable information and good at presenting to broad prospective on the topic (Green, Johnson \& Adams, 2006). Thus, most studies in this area still at the primary study stage; the narrative review is a good approach to address the aim of the present review.

\subsection{Inclusion Criteria}

Various research papers and review papers that focus on the benefits of companion dogs to older person were identified and included for the purpose of this review. These papers do not necessarily only include participants that are dog owners, but in some cases, the differences between older cats, dogs and non-pet owners were also compared and analyzed. Studies that were analyzed in this review were limited to journals or review papers that were published from year 2005 to 2015. The review includes studies from both the Western and Asian countries such as Hong Kong and Scotland. It is also important to note that the papers included in this review do not merely emphasize on the urban and industrialized city population but sample groups from villages and rural areas were also analyzed and included in some of the studies.

The selected research papers were also not limited in their research designs or methods as there are papers that were population studies, qualitative research, field research as well as questionnaire based studies. Since this review focuses on the benefits of dog ownership among older person, research papers that did not include a majority of participants above the age of 60 or do not attempt to analyze the effect of companion dog ownership for this particular age group were excluded. Research papers that focus on the benefits of Animal-Assisted Therapy (AAT) were also excluded due to the fact that animals in AAT are required to be well-trained and have higher therapeutic value. This is different from normal house pets and companion animals as they are usually not specifically trained for their therapeutic qualities and are often kept for the sake of their companionship. With the inclusion criteria being set and identified, the desired research papers were screened by looking at the title, abstract as well as discussion of the papers.

\subsection{Search Strategy}

PubMed under the U.S. National Institutes of Health's National Library of Medicine (NIH/NLM) and ProQuest were the two main search engines that were utilized in locating the necessary journals and articles for the purpose of this review. A total of 7 results were identified using the MESH term "older adults" and "dog ownership" in PubMed and 4 of these studies were included in this review. 1 particular result does not meet the inclusion criteria of this review while another 2 were not suitable for the nature of this study. 2 additional journals were also identified from ProQuest using the search term "companion dogs" and "older adults" and both studies were included in this. To ensure a more thorough search of appropriate journals and research papers, consultation on the reference lists in appropriate papers were also conducted and additional 12 studies that meet the inclusion criteria or relevant to the review were located and included for the purpose of this review.

\subsection{Analysis}

The research and review papers gathered for this review were analyzed using an evidence table that breaks the papers into sections such as sample groups, tests and instruments used, research designs, results of the studies as well as implications of the studies which could provide a straightforward and efficient look into the important characteristics of the studies.

During the review process, various benefits of companion dog ownership towards older persons were analyzed and compared among different papers and common key themes were able to be identified. The analytic approach employed in the analysis process was to analyze the prominent key themes and categorize them into physical well-being, psychological well-being and social interaction. The benefits from companion dogs to their owners in different journals were identified and included under the suitable key themes so as to provide a more comprehensive overview of the topic 
for future references.

\section{Result}

\subsection{Dogs and Physical Well-Being}

\subsubsection{Physical Activity}

Thorpe and colleagues' longitudinal study (2006) in the United States showed that $58.5 \%$ of older adult dog owners who walk their dogs would meet the recommendation of 150 minutes physical activity. Additionally, those who walk their dogs would likely to achieve to same standard of physical activities three years later as compared to those who do not walk their dogs. This is similar to another study by Feng et al (2014) which found statistically significant relationship between dog ownership and physical activity among older persons in Scotland, suggesting the probability that dog ownership may promote physical activity and helping older adults to overcome their barriers to exercise.

Relevant data were gathered and selected from the Nord-Trondelag Health Study (HUNT)-3, one of the world's largest population studies by Enmaker, Hellzen, Ekker and Berg (2012) and has given useful information in examining the association between pet-ownership and their health status. The data shows that dog owners $(n=814)$ would exercise more frequently as compared to either cat or non-pet owners. Two separate studies conducted by Rijken and Van Beek (2011) and Shibata, Oka, Inoue, Christian, Kitabatake and Shimomitsu (2012) also obtained similar results where they found that having a dog could help elderly to achieve healthy level of physical activity. Once again, similar result was also obtained in another Asian based study in Hong Kong that was conducted by Chan, Cheung and Lo (2007) which stated that some of their participants reported that walking their dog on a daily basis ensure them to exercise regularly. A coauthor of a journal article also pointed out that walking her daughter's dog on a daily basis provides her the opportunity to reflect on her past life events, goals for future and a sense of responsibility (Cangelosi \& Sorrell, 2010).

Table 1: Summary of study characteristics and benefits of owning dogs

\begin{tabular}{|c|c|c|c|c|c|}
\hline Study & Sample & Sample Size & Design & Assessment Methods & Result \\
\hline $\begin{array}{l}\text { Thorpe et al. (2006); } \\
\text { Dog ownership, walking } \\
\text { behavior, and maintained } \\
\text { mobility in late life }\end{array}$ & $\begin{array}{l}\text { community dwelling } \\
\text { older adults aged } \\
71 \text { to } 82\end{array}$ & $\begin{array}{l}\mathrm{N}=2,533 \\
\text { Dog owners }= \\
394\end{array}$ & $\begin{array}{l}\text { Cross sectional } \\
\text { and longitudinal } \\
\text { analyses of a } \\
\text { prospective } \\
\text { cohort study }\end{array}$ & $\begin{array}{l}\text { Objective measures of } \\
\text { usual or rapid walking } \\
\text { speed; face-to-face } \\
\text { interview }\end{array}$ & $\begin{array}{l}\text { Cross-sectionally, dog walkers were more likely to } \\
\text { achieve } 150 \text { minutes of walking per week and had } \\
\text { faster usual and rapid walking speeds than non-dog } \\
\text { owners who did not walk at least three times per } \\
\text { week and similar speeds as non-dog owners who } \\
\text { walked at least } 150 \text { minutes per week; dog walkers } \\
\text { were approximately twice as likely as any other } \\
\text { group to achieve recommended walking levels three } \\
\text { years later; Dog walkers experienced similar } \\
\text { declines in usual and rapid walking speed as non- } \\
\text { dog owners who walked at least three times per } \\
\text { week but maintained their initial mobility advantage }\end{array}$ \\
\hline $\begin{array}{l}\text { Feng et al. (2014); } \\
\text { Dog ownership and } \\
\text { physical activity in later } \\
\text { life: A cross-sectional } \\
\text { observational study }\end{array}$ & \begin{tabular}{|l|} 
Community \\
dwelling older \\
adults aged 65 and \\
above
\end{tabular} & $N=547$ & $\begin{array}{l}\text { Stratified } \\
\text { random } \\
\text { sampling }\end{array}$ & $\begin{array}{l}\text { Older People and Active } \\
\text { Living (OPAL) } \\
\text { questionnaire; objective } \\
\text { measure of physical } \\
\text { activity; Hospital Anxiety } \\
\text { and Depression Score } \\
\text { (HADS); SF-36 }\end{array}$ & $\begin{array}{l}\text { Dog ownership was positively related to higher PA } \\
\text { levels; Dog owners were found to be } 12 \% \text { more } \\
\text { active than non-dog owners. }\end{array}$ \\
\hline $\begin{array}{l}\text { Enmaker, Hellzen, Ekker } \\
\text { and Berg (2012); } \\
\text { Health in older cat and } \\
\text { dog owners: The Nord- } \\
\text { Trondelag Health Study } \\
\text { (HUNT)-3 study }\end{array}$ & $\begin{array}{l}\text { Older adults aged } \\
65 \text { to } 101 \text { from } \\
\text { Nord-Trondelag } \\
\text { county }\end{array}$ & $\begin{array}{l}\mathrm{N}=12,297 ; \text { Pet } \\
\text { owners }=2,358\end{array}$ & $\begin{array}{l}\text { Cross-sectional } \\
\text { population study }\end{array}$ & $\begin{array}{l}\text { Interviews; questionnaires; } \\
\text { blood and urine samples; } \\
\text { clinical examination }\end{array}$ & $\begin{array}{l}\text { Dog ownership demonstrated several health-related } \\
\text { characteristics to a higher positive degree than both } \\
\text { non-pet and cat ownership; Cat owners showed } \\
\text { higher body mass index values and higher systolic } \\
\text { blood pressure, and reported worse general health } \\
\text { status with lower degree of exercise }\end{array}$ \\
\hline $\begin{array}{l}\text { Rijken \& Van Beek } \\
\text { (2011); About Cats and } \\
\text { Dogs ... Reconsidering } \\
\text { the Relationship Between } \\
\text { Pet Ownership and Health } \\
\text { Related Outcomes in } \\
\text { Community-Dwelling } \\
\text { Elderly }\end{array}$ & $\begin{array}{l}\text { Older adults aged } \\
65 \text { and over } \\
\text { participating in } \\
\text { theNational Panel } \\
\text { of people with } \\
\text { Chronic illness or } \\
\text { Disability (NPCD) }\end{array}$ & $\mathrm{N}=1,410$ & $\begin{array}{l}\text { Cross-sectional } \\
\text { study }\end{array}$ & $\begin{array}{l}\text { General Health } \\
\text { Questionnaire (GHQ-12); } \\
\text { RAND-36 Short Form } \\
\text { Health Status Survey; } \\
\text { SQUASH; UCLA } \\
\text { Loneliness Scale; SCP- } \\
\text { physical disability indicator }\end{array}$ & $\begin{array}{l}\text { Pet ownership was associated with a greater } \\
\text { chance of using ambulatory mental healthcare but } \\
\text { not related to self-reported general or mental health; } \\
\text { associations between pet ownership and the } \\
\text { frequency of social contacts or feelings of loneliness } \\
\text { were not found; having a dog increased the } \\
\text { likelihood of being healthy active, whereas having a } \\
\text { cat showed the opposite }\end{array}$ \\
\hline $\begin{array}{l}\text { Shibata, Oka, Inoue, } \\
\text { Christian, Kitabatake \& } \\
\text { Shimomitsu (2012); }\end{array}$ & $\begin{array}{l}\text { Community } \\
\text { dwelling older } \\
\text { adults aged } 65 \text { to }\end{array}$ & $\mathrm{N}=1926$ & $\begin{array}{l}\text { Population- } \\
\text { based cross } \\
\text { sectional study }\end{array}$ & \begin{tabular}{|l|} 
International Physical \\
Activity Questionnaire short \\
version (IPAQ-SV); SF-8 \\
\end{tabular} & $\begin{array}{l}\text { Dog walkers reported more minutes/week of } \\
\text { moderate-to-vigorous physical activity and total } \\
\text { physical activity than both non-dog walkers and }\end{array}$ \\
\hline
\end{tabular}




\begin{tabular}{|c|c|c|c|c|c|}
\hline $\begin{array}{l}\text { Physical Activity of } \\
\text { Japanese Older Adults } \\
\text { Who Own and Walk Dogs }\end{array}$ & 74 & & & & $\begin{array}{l}\text { non-dog owners; dog walkers also walked more } \\
\text { minutes per week than non-dog owners; dog } \\
\text { walkers were more likely to be sufficiently active than } \\
\text { both non-dog walkers and non-dog owners }\end{array}$ \\
\hline $\begin{array}{l}\text { Chan, Cheung \& Lo } \\
\text { (2007); An exploratory } \\
\text { study of pet raising and } \\
\text { health of the elderly } \\
\text { people in Hong Kong }\end{array}$ & $\begin{array}{l}\text { Older adults aged } \\
65 \text { and above }\end{array}$ & $\mathrm{N}-20$ & $\begin{array}{l}\text { Cross sectional } \\
\text { qualitative study }\end{array}$ & In-depth interview & $\begin{array}{l}\text { Pet owners reported positive impacts on their } \\
\text { physical, psychological and social health; non-pet } \\
\text { owners reported potential issues such as allergy and } \\
\text { inability to control their pets given the older adults' } \\
\text { general physique }\end{array}$ \\
\hline $\begin{array}{l}\text { Putney (2014); } \\
\text { Older Lesbian Adults' } \\
\text { Psychological Well- } \\
\text { Being: The Significance of } \\
\text { Pets }\end{array}$ & $\begin{array}{l}\text { Older lesbian adults } \\
\text { aged } 65 \text { to } 80\end{array}$ & $\mathrm{~N}=12$ & $\begin{array}{l}\text { Purposive and } \\
\text { snowball } \\
\text { sampling; } \\
\text { qualitative study }\end{array}$ & $\begin{array}{l}\text { open-ended, } \\
\text { semistructured, exploratory } \\
\text { interview questions }\end{array}$ & $\begin{array}{l}\text { Two intertwined thematic findings framed as "love" } \\
\text { and "caregiving" were identified }\end{array}$ \\
\hline $\begin{array}{l}\text { Motooka, Koike, } \\
\text { Yokoyama \& Kennedy } \\
\text { (2006); Effect of dog- } \\
\text { walking on autonomic } \\
\text { nervous activity } \\
\text { in senior citizens }\end{array}$ & $\begin{array}{l}\text { Older adults with } \\
\text { mean age of } 67.5\end{array}$ & $\mathrm{~N}=13$ & \begin{tabular}{|l|} 
Controlled \\
crossover study
\end{tabular} & $\begin{array}{l}\text { High frequency (HF) power } \\
\text { value of heart rate } \\
\text { variability for } \\
\text { parasympathetic neural } \\
\text { activity }\end{array}$ & $\begin{array}{l}\text { During dog-walking, HF power increased } \\
\text { significantly and this increase was sustained } \\
\text { throughout each dog walk, and was more } \\
\text { pronounced during succeeding dog walks; at home, } \\
\text { HF power was } 1.87 \text { times greater when the dog was } \\
\text { present, and } 1.57 \text { times greater than in the walking } \\
\text { experiment }\end{array}$ \\
\hline $\begin{array}{l}\text { Winefield, Black \& Chur- } \\
\text { Hansen (2008); Health } \\
\text { effects of ownership of } \\
\text { and attachment to } \\
\text { companion animals in an } \\
\text { older population. }\end{array}$ & $\begin{array}{l}\text { Community living } \\
\text { older adults }\end{array}$ & $\mathrm{N}=314$ & $\begin{array}{l}\text { Cross-sectional } \\
\text { study }\end{array}$ & $\begin{array}{l}\text { Interview with structured } \\
\text { questions and standardized } \\
\text { scales }\end{array}$ & $\begin{array}{l}\text { Neither pet ownership nor pet attachment added } \\
\text { significantly to explained variance in health and well- } \\
\text { being }\end{array}$ \\
\hline $\begin{array}{l}\text { Scheibeck, Pallauf, } \\
\text { Stellwag \& Seeberger } \\
\text { (2011); Elderly people in } \\
\text { many respects benefit } \\
\text { from interaction with dogs }\end{array}$ & $\begin{array}{l}\text { Older adults aged } \\
70 \text { and above }\end{array}$ & $\mathrm{N}=23$ & $\begin{array}{l}\text { Qualitative } \\
\text { social research; }\end{array}$ & $\begin{array}{l}\text { Ethnographic interview; } \\
\text { ethnographic field research }\end{array}$ & $\begin{array}{l}\text { Dogs could provide opportunities for social contact, } \\
\text { structures in daily lives and a sense of purpose and } \\
\text { responsibilities }\end{array}$ \\
\hline $\begin{array}{l}\text { Knight \& Edwards (2008). } \\
\text { In the company of wolves: } \\
\text { The physical, social, and } \\
\text { psychological benefits of } \\
\text { dog ownership }\end{array}$ & $\begin{array}{l}\text { Dog walkers aged } \\
28 \text { and } 85 \text { with a } \\
\text { mean age of } 60\end{array}$ & $\mathrm{~N}=62$ & $\begin{array}{l}\text { Qualitative } \\
\text { study }\end{array}$ & Focus group discussion & $\begin{array}{l}\text { Interaction between humans and dogs can enhance } \\
\text { the physical and psychological health of older adults } \\
\text { and promote a social support network between dog } \\
\text { owners which could alleviate dependence and } \\
\text { impact on health and social services }\end{array}$ \\
\hline $\begin{array}{l}\text { Pikhartova, Bowling \& } \\
\text { Victor (2014); Does } \\
\text { owning a pet protect older } \\
\text { people against } \\
\text { loneliness? }\end{array}$ & $\begin{array}{l}\text { Community } \\
\text { dwelling population } \\
\text { aged } 50 \text { and above }\end{array}$ & $N=5,210$ & $\begin{array}{l}\text { Longitudinal } \\
\text { study of ageing }\end{array}$ & $\begin{array}{l}\text { UCLA Loneliness Scale; } \\
\text { NS-SEC } 3 \text { Short version }\end{array}$ & $\begin{array}{l}\text { The association between pet ownership and } \\
\text { loneliness is stronger in women than men; age, } \\
\text { social relationships, demographic factors and health } \\
\text { behaviour variables have only a minimal influence } \\
\text { upon the association between loneliness and pet } \\
\text { ownership; women who reported being lonely were } \\
\text { more likely to have a pet }\end{array}$ \\
\hline $\begin{array}{l}\text { Gulick, \& Krause-Parello } \\
\text { (2012); } \\
\text { Factors related to type of } \\
\text { companion pet owned by } \\
\text { older women }\end{array}$ & $\begin{array}{l}\text { Older female per- } \\
\text { owner aged } 55 \text { to } \\
84\end{array}$ & $\mathrm{~N}=159$ & $\begin{array}{l}\text { Cross-sectional } \\
\text { study }\end{array}$ & $\begin{array}{l}\text { Psychological General } \\
\text { Well-being Index; UCLA } \\
\text { Loneliness Scale }\end{array}$ & $\begin{array}{l}\text { Women with companion dogs had significantly } \\
\text { higher levels of depressed mood and higher levels of } \\
\text { general health, vitality, and total subjective well- } \\
\text { being than women with companion cats }\end{array}$ \\
\hline $\begin{array}{l}\text { Krause-Parello (2012); } \\
\text { Pet ownership and older } \\
\text { women: The relationships } \\
\text { among loneliness, pet } \\
\text { attachment support, } \\
\text { human social support and } \\
\text { depressed mood }\end{array}$ & $\begin{array}{l}\text { Pet-owning older } \\
\text { female aged } 55 \text { to } \\
84\end{array}$ & $\mathrm{~N}=159$ & $\begin{array}{l}\text { Cross-sectional } \\
\text { study }\end{array}$ & $\begin{array}{l}\text { Psychological Well-being } \\
\text { Schedule (PGWB); Pet } \\
\text { Attachment Scale; UCLA } \\
\text { Loneliness Scale; Coping } \\
\text { Strategy Indicator (CSI) }\end{array}$ & $\begin{array}{l}\text { There is significant relationship between loneliness, } \\
\text { pet attachment support, human social support, and } \\
\text { depressed mood; No relationship was found } \\
\text { between human social support and depressed } \\
\text { mood; Pet attachment support influenced the } \\
\text { relationship between loneliness and depressed } \\
\text { mood }\end{array}$ \\
\hline $\begin{array}{l}\text { Parslow, Jorm, } \\
\text { Christensen, Rodgers, \& } \\
\text { Jacomb (2005); Pet } \\
\text { ownership and health in } \\
\text { older adults: Findings } \\
\text { from a survey of } 2,551 \\
\text { community-based } \\
\text { Australians aged } 60-64\end{array}$ & $\begin{array}{l}\text { Community based } \\
\text { older adults aged } \\
60 \text { to } 64\end{array}$ & $\mathrm{~N}=2,551$ & $\begin{array}{l}\text { Longitudinal } \\
\text { study }\end{array}$ & $\begin{array}{l}\text { 12-item Short-Form Health } \\
\text { Survey (SF-12); Goldberg's } \\
\text { Scales; Positive and } \\
\text { Negative Affect Scale } \\
\text { (PANAS); Eysenck } \\
\text { Personality Questionnaire } \\
\text { Revised (EPQ-R) }\end{array}$ & $\begin{array}{l}\text { Pet-owners reported more depressive symptoms } \\
\text { while female pet owners who were married also had } \\
\text { poorer physical health; Caring for a pet was } \\
\text { associated with negative health outcomes; No } \\
\text { relationship was found between pet ownership and } \\
\text { use of GP services; men who cared for pets had } \\
\text { higher extraversion score; pet owners and carers } \\
\text { reported higher levels of psychoticism }\end{array}$ \\
\hline $\begin{array}{l}\text { Fitzpatrick, Moore, } \\
\text { Bingham, Mel, Dow \& } \\
\text { Haralambous (2008); } \\
\text { Identifying the need for } \\
\text { companion animal support } \\
\text { for the home and } \\
\text { community care target } \\
\text { population }\end{array}$ & $\begin{array}{l}\text { Community care } \\
\text { service provider; } \\
\text { community care } \\
\text { service user }\end{array}$ & $\begin{array}{l}\text { Service } \\
\text { provide= 78; } \\
\text { Service user= } \\
601\end{array}$ & $\begin{array}{l}\text { Cross-sectional } \\
\text { study }\end{array}$ & $\begin{array}{l}\text { Service User Survey; } \\
\text { Service Provider Survey }\end{array}$ & $\begin{array}{l}\text { Various accounts on the positive } \\
\text { influence of companion animals on the emotional, } \\
\text { physical, social health and well being of older people } \\
\text { and people with disabilities were reported in the } \\
\text { survey }\end{array}$ \\
\hline
\end{tabular}


However, as pointed out by Feng and colleagues (2014), dog ownership does not necessarily means dog walking as shown by the study conducted by Thorpe et al (2006) where only $36 \%$ of the 394 dog owners would walk their dog regularly. Therefore, the role of older adult owners is crucial in obtaining the potential physical benefit of companion dog.

\subsubsection{Physical Health}

In a recent qualitative study by Putney (2014) that focuses on older lesbian adults, certain participants have reported that taking their dogs on regular walks have helped in alleviating their arthritis pain. On the other hand, Rjiken and Van Beek's (2011) study has stated that dog or pet ownership does not seem to contribute to the perceived general health and mental health as rated by the elderly participants themselves. However, it should also be noted that all the participants in their study suffers from a certain form of physical illness or disabilities, and this could account for result of no perceived correlation between pet ownership and general or mental health. In contrast, Enmarker and colleagues (2012) found that dog owners would rate their health as better as compared to cat or non-pet owners.

In another study that focuses on older Japanese adults, dog walking was also found to be able to shift their autonomic nervous activity in favor of parasympathetic activity (Motooka, Koike, Yokoyama and Kennedy, 2006). The study proposed that the suppression of sympathetic nervous activity was not merely affected by walking the dog but could also be influenced by paying attention and being with the dog itself. Furthermore, even in the case of those who could not walk their dog or exercise, the act of spending time with their dog alone could also have a stabilizing effect on their heart rate.

Nevertheless, Chan and colleagues' (2007) study noted that one of the research participants reported suffering from cough ever since he or she started having a companion dog which could probably be attributed to virus infection through the air or allergy reaction. This report illustrates the fact that having a companion dog might also have adverse health effect on certain people. Winefield, Black and Chur-Hansen (2008) also found that pet ownership and pet attachment does not seem to provide significant effect on health and well-being but daily exercise would be more reliable in obtaining good health.

\subsection{Dogs and Social Contact}

Aside from promoting better health and increasing physical activity among older persons, companion dogs could also play a part in increasing the opportunities of social contact of their owners. In a study conducted by Scheibeck, Pallauf, Stellwag and Seeberger (2011) that utilizes ethnographic field research, the researchers were able to obtain responses from participants such as "when I'm outside with my dog, I always meet new people and chat with them" that could support this hypothesis. In addition, the researchers also conducted structured small-talk conversations with older persons who used to own dogs in three different dog cemeteries in Austria. Once again, participants of the study also provided similar answers such as "I always meet people here who also used to have a dog, like me, so you can talk to them about it". These answers gathered in the study demonstrate the abilities of dogs to promote social contact with other people by acting as catalysts. A similar result was obtained in another study conducted by Chan and colleagues (2007) where older dog owners reported that they were able to meet new people by talking to others about their dogs or sharing their experience in caring for their dogs together.

In addition, two participants in Putney's (2014) study who faces impairment in mobility would rely on dog walkers to walk their dogs and at the same time, the presence of the dog walkers would provide opportunities for social contact as the participants are homebound and have decreased frequency in social contact outside of their home. Another research conducted by Knight and Edwards (2008) states that dog owners are better in overcoming personal barriers such as minor illness and depression to walk their dogs on a daily basis, thus increasing their likelihood of social contact. Nevertheless, it should be noted that a study conducted by Rjiken and Van Beek (2011) found that pet ownership does not correlate significantly with social contacts with friends, acquaintances or neighbors which contradicts with several other findings that focuses on this particular aspect of the human-dog relationship.

\subsection{Dogs and Companionship}

Dogs are often said to be loyal animals and this particular characteristic could often provide their owners a sense of companionship. In Putney's (2014) study, participants have reported feelings of comfort by the consistent and predictable existence of their companion dogs in their daily lives. The feeling of companionship is not only limited to the sense of having an animal to accompany a person in their daily life or paying attention to them as another respondent in the study 
has pointed out that both she and her dog were experiencing substantial medical issues that have affected their mobility but she believes that the timing is right for both of them as they both could hardly walk for an extended amount now. This form of symmetry human-animal well-being could also contribute to the sense of companionship felt by an individual as they are both facing similar situation together, thus, providing support and strength to each other in overcoming the hardship and obstacle.

There is also result that suggests the association between pet ownership and loneliness is more prominent in women as compared to other demographic variables such as age and health behaviors (Pikhartova, Bowling and Victor, 2014). The study found that the association between pet ownership (with a huge percentage of dog owners) and loneliness is more confined to women where their result demonstrates that women who always reported being lonely or those women who have overcame their loneliness were more likely to have pets.

It was also found that having dogs could make older people feel less lonely as they could feel the support from their pets, which could be seen from the verbatim by one of the participants in Chan and colleagues' (2007) study that states "when I feel lonely, I can talk to him, he makes me happy". The companionship provided by dogs to their owners was found by the Chan and colleagues' (2007) study to be applicable to both the older persons living in villages or public estates. Similarly, another research focuses on older women between the ages of 55 to 84 also found that significantly more women who were married or partnered have dogs whereas a higher amount of women who are single tend to own cats instead (Gulick \& Krause-Parello, 2012). This study also found that female participants who have dogs reported significantly lower depressed mood, higher degree of general health, vitality and general well-being as compared to older female cat owners which may be attributed to the fact that companion dogs often require a higher degree of physical care. Another study by Krause-Parello (2012) also found that pet attachment appears to be able to provide a greater support as compared to human social support in her study involving 159 pet-owning older women.

\subsection{Dogs and Psychological Well-Being}

In contrast to popular belief that there exist positive correlations between dog ownerships and owners' general well-being, a study by Parslow, Jorm, Christensen, Rodgers and Jacomb (2005) has found that pet owners have reported more depressive symptoms as compared to non-pet owners along with poorer physical health among married female pet owners. This finding diverged from another research done by Krause-Parello (2012) which proposed that pet-owning older women with tend to exhibit fewer depressive symptoms possibly due to a lower level of loneliness.

In another research by Fitzpatrick and colleagues (2008), the need for companion animal support within the health centers for older people was examined. Questionnaires were handed out to health care service providers in which different aspects of pet ownership among ageing clients were examined. In relation to the quality of life among ageing clients with regards to their pet ownership status, many of the service providers have reported that having pets do contribute to the general well-being of some of the clients in the service centers. Some service providers stated their clients told them that "they tell their dogs and cats all their worries" and some of them regained the will to live as they need to care for their pets after their significant partners passed away. Nevertheless, since taking care of pets such as dogs requires huge commitment and energy, some respondents in the study also believe that "in some instances, not all, it could be another stressor to them". The study also found that in this sample of older people and people with disabilities, over $90 \%$ of them who are pet owners felt that their pets are part of the family and is "very important" or "essential" to their general well-being.

Study by Chan and colleagues (2007) found that older dog owners have reported improvement in their temper as they are able to react more positively during their interaction with other people and became less irritable in their daily lives. On the other hand, the study also found that despite the positive effects of dog ownership have on their older owners, there exists certain possibilities of adverse effects following the death or separation of their companion animals, which could leave their owners feeling sad and distressed. In the study by Putney (2014), participants have also reported that having pets such as dogs could help to alleviate their stress. It was stated by the respondents of the study that these pets could act as a welcome interruption in their daily lives as they would need to tend to their pets' needs. This would also create daily structures in their lives and thus, helping them to focus, providing them with a sense of accomplishments and making they feel skilled and capable.

\section{Discussion}

Many of the studies included in this review analyze the effects of companion dogs on older persons in terms of physical well-being, psychological well-being and social interaction. In an attempt to understand the benefits of human-dog 
relationship, various methods were utilized in obtaining data and responses which include questionnaires targeting health service providers, population studies, interviews and qualitative studies. Each and every one of these research designs provide different perspectives and contributions on the topic as they could either be a first person account on the effects of companion dogs on the owners themselves (Chan et al., 2007; Scheibeck et al., 2011; Putney, 2014) or a more scientific approach in obtaining data and effects of dog walking on the health among older person by using palm-sized electrocardiographic monitor (Motooka et al., 2006).

Some of the researches included in this review were unable to effectively identify the causal-relationship of the effects of companion dogs on their owners. This is mainly attributed to the research designs that were unable to control confounding variables such as population studies that could only compare demographic data and health-related statistics along with pet ownership status among the participants. One of the much speculated confounding variables could be personalities of pet owners and type of pets chosen or pet ownership status. Parslow and colleagues (2005) have found that men who care for pets appears to have higher level of extraversion and pet owners also appear to have significantly higher level of psychoticism when compared to non-pet owners. However, such results are not consistent with another study by Johnson and Rule (1991) have discovered that no significant differences exists in neuroticism, extraversion, selfesteem and social behavior between pet owners and non-pet owners. Another recent study by Enmarker, Hellzen, Ekker and Berg (2013) shows that dog ownership is more strongly linked to extraversion and higher sociability probably due to the fact that caring for dogs would often require dog walking, which would lead to higher opportunities of social contact with people, something that might be avoided by people who are more introverted. It is therefore possible that if the type of personalities could affect a person's choice in choosing a pet, it could serve as a confounding variable that could affect the outcome of studies that aim to analyze the benefits of dog ownership on their owners.

As illustrated in the above findings, many research have shown similar patterns of inconsistent correlation regarding the effects of dog ownership and the direction of relationship is unclear and not always positive. Nevertheless, research designs that allow researchers to directly interview participants or their health care service providers could also help to obtain a clearer picture and better understanding on this relationship. As seen in Fitzpatrick and colleagues' (2008) study, health care service providers reported that "a lot of clients enjoy having another living thing in their house. Many clients say they only enjoy living to look after their animal". Comments and feedback such as these demonstrates that dog ownerships do play a part in contributing to the well-being of older person and in some cases; it will provide them with the will to live.

However, having pets such as dogs at home also require a certain level of dedications and responsibilities from the owner as they will have to tend to the needs of their companion dogs. In situations where the older owners have to surrender their pets due to their inability to care for them, it could cause the older person distress and pain, which might affect their emotional well-being (Fitzpatrick et al., 2008). Besides that, hygiene issues and allergic reactions could also be a concern when it comes to dog ownership among older persons (Chan et al., 2007). In addition, a systematic review conducted by Islam and Towell (2013) found no clear relationship between pet ownership and owner's general well-being which does not warrant the necessity of having a companion dog at home for some older persons. Even though there appears to be some difficulties in having companion dogs as well as distress following separation and death of companion dogs, there are undeniably many benefits of introducing companion dogs into the lives of older persons.

According to the latest WHO global strategy on diet, physical activity and health, the recommended levels of physical activity for adults age 65 and above should include a minimum of at least 150 minutes of moderate-intensity aerobic physical activities throughout the week (WHO, 2014). This includes leisure time physical activities such as walking, swimming, games and sports. One of the strategies that could promote regular walking among older person includes walking their pet dogs as these canine companions often require consistent amount of exercise in order to stay fit and healthy. Aside from achieving the recommended level of physical activities through walking their dogs, older person would also be able to benefit from the regular exercise which could promote their physical activities and health.

Motivation to walk their dog, heightened chance of social contact, sense of security as well as companionship provide by pet dogs are clear indications that companion dogs do play a significant role in improving the general wellbeing of older adult dog owners. If the causal relationship between the benefits of dog ownership and owner's well-being could be strongly asserted, then the therapeutic value of companion dogs would be better appreciated. In-depth studies are undoubtedly required in order to further determine the benefits of companion dogs on their owner and to explore this relationship more thoroughly. Length of ownership, the attachment to their dogs, how the pet ownership is defined in the research are all important variables in determining the quality of the human-companion animals relationship and by employing a more structured and in-depth research design and analysis, the effect of the relationship will be better defined. 


\section{Advantages and Disadvantages}

This review aims to provide a comprehensive understanding on the effects of dog ownership amongst older person. This paper collects a wide range of research that was targeted at various population samples which includes Western countries, Asian countries as well as urban and rural areas. By including research that was based on different populations, a more culturally appropriate comparison could be made and thus, a higher level of external validity might be achieved.

However, a disadvantage of this review is that only a limited number of Asian based papers were included in this review. This could limit the ability of the paper to generalize and compare itself with the other Asian countries due to the fact that Asia consists of diverse and multicultural and ethnic groups and the limited Asian based studies were not enough to obtain a clear picture of the relationship between companion dogs and their owners in certain countries.

\section{Conclusion}

Dog ownership could affect a person's well-being in multiple ways and most often than not, these benefits also extends to the older person population. By analyzing the various researches included in this review, we could observe that dogs have the abilities to affect the lives of their owners either directly or indirectly. By understanding this relationship and the effects the companion dogs have on their owners as well as those around them, we could perhaps learn to appreciate them more and at the same time, helping older person to improve their overall quality of life via human-companion dog relationship. In conclusion, dog ownership might not be suitable for everyone and might even be burdensome to some, however, for those who are fortunate enough to have companion dogs in their lives, they will be able to enjoy the benefits and joy of having a loyal friend and companion who would be with them with all their heart and soul.

\section{References}

Allen, K. M., Blascovich, J., Tomaka. J., \& Kelsey, R. M. (1991). Presence of human friends and pet dogs as moderators of autonomic responses to stress in women. Journal of Personality and Social Psychology. 61(4), 582-589. Retrieved from https://www.calvin.edu/ rpruim/courses/m143/articles/PetstressArticle.pdf

Cangelosi, P. R., \& Sorrell, J. M. (2010). Walking for therapy with man's best friend. Journal of Psychosocial Nursing and Mental Health Services, $\quad 48(3), \quad$ 19-22. Retrieved from http://search.proquest.com.esearch.ut.edu/docview /225529889/fulltext/A66B0F96A9B144FBPQ/2?accountid=14762

Chan, C. M. A., Cheung, K. W. K., \& Lo, L. F. (2007). An exploratory study of pet raising and health of the elderly people in Hong Kong. Retrieved from APIAS Monograph 專題論文.

Cipriani, A \& Geddes, J. (2003). Comparison of systematic and narrative reviews: the example of the atypical antipsychotics. Epidemiologia e Psichiatria Sociale, 12(3), 146 - 154.

Enmarker, I., Hellzen, O., Ekker, K., \& Berg, A. (2012). Health in older cat and dog owners: The Nord-Trondelag Health Study (HUNT)-3 study. Scandinavian Journal of Public Health. 40. 718-724. doi: 10.1177/1403494812465031

Enmarker, I., Hellzen, O., Ekker, K., \& Berg, A. T. (2013). Personalities and health in older cat and dog owners: A HUNT-study. Health. 5(9), 1449-1454. doi: 10.4236/health.2013.59197

Feng, Z., Dibben, C., Witham, M. D., Donnan, P. T., Vadiveloo, T., Sniehotta, F., ... McMurdo, M. E. T. (2014). Dog ownership and physical activity in later life: A cross-sectional observational study. Preventive Medicine, 66, 101-106. doi: 10.1016/j.ypmed.2014.06.004.

Garg, A.X., Hackam, D. \& Tonelli, M. (2008). Systematic Review and Meta-analysis: When One Study is just not enough. Clinical Journal of the American Society Nephrology, 3: 253-260. doi: 10.2215/CJN.01430307

Green, B.N., Johnson, C.D., Adams, A. (2006). Writing narrative literature reviews for peer-reviewed journals: secrets of the trade. Journal of Chiropractic Medicine, 5(3), $101-117$.

Gulick, E. E., \& Krause-Parello, C. A. (2012). Factors related to type of companion pet owned by older women. Journal of Psychosocial Nursing and Mental Health Services, 50(11), 30-37. Retrieved from http://search.proquest.com.esearch.ut.edu/docview /1139769590/fulltext/A66B0F96A9B144FBPQ/1?accountid=14762

Islam, A., \& Towell, T. (2013). Cat and dog companionship and well-being: A systematic review. International Journal of Applied Psychology. 3(6), 149-155. doi: 10.5923/j.ijap.20130306.01

Johnson, S. B., \& Rule, W. R. (1991). Personality characteristics and self-esteem in pet owners and nonowners. International Journal of Psychology, 26, 241-252

Knight, S., \& Edwards, V. (2008). In the company of wolves: The physical, social, and psychological benefits of dog ownership. Journal of Aging Health, 20, 437-455. doi: 10.1177/0898264308315875

Krause-Parello, C. A. (2012). Pet ownership and older women: The relationships among loneliness, pet attachment support, human social support and depressed mood. Geriatric Nursing, 33(3), 194-203. doi: 10.1016/j.gerinurse.2011.12.005 
McConnell, A. R., Brown, C. M., Shoda, T. M., Stayton, L. E. \& Martin, C. E. (2011). Friends with benefits: On the positive consequences of pet ownership. Journal of Personality and Social Psychology. 101(6), 1239-1252. doi: 10.1037/a0024506

Motooka, M., Koike, H., Yokoyama, T., \& Kennedy, N. L. (2006). Effect of dog-walking on autonomic nervous activity in senior citizens. Medical Journal of Australia. 184(2), 60-63. Retrieved from https://www.mja.com.au/journal/2006/184/2/effect-dog-walkingautonomic-nervous-activity-senior-citizens

Parslow, R. A., Jorm, A. F., Christensen, H., Rodgers, B., \& Jacomb, P. (2005). Pet ownership and health in older adults: Findings from a survey of 2,551 community-based Australians aged 60-64. Gerontology. 51, 40-47. doi: 10.1159/000081433

Pikhartova, J., Bowling, A., \& Victor, C. (2014). Does owning a pet protect older people against loneliness? BMC Geriatrics. 14(106). doi: 10.1186/1471-2318-14-106

Pet Food Manufacturers' Association (PFMA). (2013). Pet Population 2013. Retrieved October 24, 2014, from http://www.pfma.org.uk/pet-population

Putney, J. M. (2014). Older lesbian adults' psychological well-being: The significance of pets. Journal of Gay \& Lesbian Social Services. 26(1), 1-17. doi: 10.1080/10538720.2013.866064

Real Animals Pets and People, The National Ageing Research Institute. (2008). Identifying the need for companion animal support for the home and community care target population. Retrieved from http://www.mednwh.unimelb.edu.au/nari_research Ipdf_docs/NARI-Companion-Animals-Final_Report.pdf

Rijken, M., \& Beek, S. van. (2011). About cats and dogs... Reconsidering the relationship between pet ownership and health related outcomes in community-dwelling elderly. Social Indicators Research, 102(3), 373-388. doi: 10.1007/s11205-010-9690-8

Scheibeck, R., Pallauf, M., Stellwag, C., \& Seeberger, B. (2011). Elderly people in many respects benefit from interaction with dogs. European Journal of Medical Research. 16(12). 557-563. doi: 10.1186/2047-783X-16-12-557

Serpell, J. A. (1990). Evidence for long term effects of pet ownership on human health. Pets, Benefits and Practice. Waltham Symposium 20. Retrieved from http://www. petpartners.org/document.doc?id=44

Shibata, A., Oka, K., Inoue, S., Christian, H., Kitabatake, Y., \& Shimomitsu, T. (2012). Physical activity of Japanese older adults who own and walk dogs. American Journal of Preventive Medicine, 43(4), 429-433. doi: 10.1016/j.amepre.2012.06.019

Thorpe, R. J., Simonsick, E. M., Brach, J. S., Ayonayon, H., Satterfield, S., Harris, T. B., ... Kritchevsky, S. B. (2006). Dog ownership, walking behavior, and maintained mobility in later life. Journal of the American Geriatrics Society, 54(9), 1419-1424. Retrieved from http://onlinelibrary.wiley.com.esearch.ut.edu/doi/10.1111/j.1532-5415.2006.00856.x/pdf

Toohey, A. M., \& Rock, M. J. (2011). Unleashing their potential: a critical realist scoping review of the influence of dogs on physical activity for dog-owners and non-owners. International Journal of Behavioral Nutrition and Physical Activity. 8(46). doi: $10.1186 / 1479-5868-8-46$

United Nations (UN). Department of Economic and Social Affairs. (2013). World Population Ageing. Retrieved October 24, 2014, from http://www.libraries.psu.edu/content/dam/psul/up/lls/documents/APA_Quick_Citation_Guide.pdf

Winefield, H. R., Black, A., \& Chur-Hansen, A. (2008). Health effects of ownership of and attachment to companion animals in an older population. International Journal of Behavioral Medicine, 15, 303-310. doi: 10.1080/10705500802365532

World Health Organization (WHO). (2014). Physical Activity and Older Adults. Retrieved October 24, 2014 from http://www.who.int/dietphysicalactivity/factsheet_olderadults/en/ 